ROZVOJ INFRASTRUKTURY KOMUNÁLNÍHO PODNIKÁNÍ V KONTEXTU EXTERNÍHO ZAJIŠŤOVÁNÍ KOMUNÁLNÍCH SLUŽEB

\title{
DEVELOPMENT OF INFRASTRUCTURE OF THE MUNICIPAL ENTERPRENEURSHIP IN THE CONTEXT OF THE OUTSOURCED PROVIDING FOR MUNICIPAL SERVICES
}

Karel LACINA, prof. PhDr. DrSc., university professor University of Finance and Administration Address: $\quad$ CZ- 10100 Praha 10, Estonská 500

E-mail: $\quad$ kar.lacina@seznam.cz

\section{Hana MATOUŠKOVÁ, PhD student}

University of South Bohemia, Faculty of Economics

Address: $\quad$ CZ-370 05, České Budějovice, Studentská 13

E-mail: $\quad$ hana.matouskova@email.cz 


\title{
ROZVOJ INFRASTRUKTURY KOMUNÁLNÍHO PODNIKÁNÍ V KONTEXTU EXTERNÍHO ZAJIŠŤOVÁNÍ KOMUNÁLNÍCH SLUŽEB
}

\section{DEVELOPMENT OF INFRASTRUCTURE OF THE MUNICIPAL ENTERPRENEURSHIP IN THE CONTEXT OF THE OUTSOURCED PROVIDING FOR MUNICIPAL SERVICES}

Key words: municipal services, municipal enterprise, privatization of the public services sector

\begin{abstract}
:
The aim of the paper is to discuss the situation of the municipal enterpreneurship in some EU member countries (namely Great Britain, France, Germany, Austria and Scandinavian countries) with regards to the process of privatization running out since later 1970s and the subsequent outsourcing of contracting the municipal service provision by private companies. This situation was related to the shortage within public budgets as well to the influence of the so called New Public Management ideas. The findings are compared with the situation in the Czech Republic. The fully privatized sector of municipal services did not show to be the best way of how to provide citizens with such services. The procurement of public services for individual settlements proved to be quite successful by means of collective communal enterprises or through the joint contracting of these services by a group of municipalities with the private entities in Western countries. Unfortunately such a co-operation does not find place in the Czech Republic.
\end{abstract}

Klíčová slova: komunální služby, komunální podnik, privatizace sektoru veřejných služeb

\begin{abstract}
:
Cílem tohoto článku je diskutovat situaci komunálního podnikání ve vybraných členských zemích Evropské unie (konkrétně Velké Británie, Francie, Německa, Rakouska a Skandinávských zemí) s ohledem na proces privatizace probíhající od konce 70 . let 20. století a následné kontraktování dodávek komunálních služeb prostřednictvím soukromých podnikatelských subjektů. Tato situace souvisela s nedostatkem finančních prostředkủ ve veřejných rozpočtech a také sprosazujícími se neoliberálními myšlenkami tzv. New Public Managementu. Zjiššení jsou srovnávána se situací v České republice. Úplná privatizace sektoru komunálních služeb se neukázala být nejlepší cestou pro poskytování těchto služeb obyvatelstvu. Naopak se v západoevropských zemích ukázalo poměrně úspěšným poskytování veřejných služeb pro jednotlivé obce prostřednictvím kolektivních komunálních podniků nebo cestou společného objednávání těchto služeb sdružením obcí u soukromých subjektů. Bohužel tento druh spolupráce dosud nenalezl své místo v České republice.
\end{abstract}

\section{ÚVOD}

Komunální podniky (též nazývány municipálními nebo obecními podniky se řadí vedle státních podniků mezi tzv. podniky veřejného sektoru nebo veřejné podniky. Veřejné podniky - až na výjimky - neusilují o dosažení zisku. Patří mezi neziskové organizace a pracují na základě (Wöhe a Kislingerová, 2007):

- principu krytí nákladů (městské vodárny, městské mateřské školy)

- příspěvkového principu (např. muzea, divadla, sociální zařízení 
Pro komunální podniky je charakteristické vlastnictví samosprávným celkem či obcí a hlavní rozhodovací kritérium, kterým je veřejný zájem (Ochrana, Pavel, Vítek, 2010). Veřejný zájem je charakteristický pro poskytování „veřejných služeb“. Přestože jejich přesné vymezení je problematické (Ochrana, 2003). Rozumí se jimi zpravidla druh služeb, jejichž uživatelem (spotřebitelem) je veřejnost (občané) jako sociální subjekt. I z uvedených důvodů jsou produkovány, zabezpečovány či regulovány orgány veřejné správy.

V západoevropských, severoevropských a jihoevropských zemích ještě v šedesátých letech minulého století, s výjimkou zdravotnických zařízení, municipální podniky technické povahy takřka výlučně zabezpečovaly absolutní většinu veřejných a veřejně prospěšných služeb pro občany. Situace se v daném směru začala podstatně měnit pod vlivem napjatých veřejných rozpočtů vyvolaných změnami v systému světového hospodářství (Aucoin, 1990) a ve svém důsledku pod vlivem neoliberální politiky (Wollmann, 2011) - tzv. konceptů New Public Management - od konce sedmdesátých let, kdy byl zahájen proces privatizace a následného kontrahování převážné většiny zmíněných služeb. Byl zahájen v roce 1979 ve Velké Británii, kdy dolní sněmovna britského parlamentu schválila zákon o povinném kontrahování služeb (Compulsary Competitive Tenderring Act).

Tento proces v celé řadě prrípadů nastartoval v reakci na četné analýzy, poukazující na vyšší náklady státem a obcemi vlastněných podniků ve srovnání s obdobnými soukromými provozy (Boycko, Shleifer a Vishny, 1996). Jak se později ukázalo, jakkoli v řadě případů soukromé podniky dokážou zajišš'ovat požadované služby v dostatečné šiři za adekvátních podmínek (Hebdon a Jalette, 2008), privatizace komunálních služeb rozhodně není všelékem (Dilger, Moffett, a Struyk, 1997). Ani čistě soukromé ani čistě veřejné zajišt'ování těchto služeb se totiž dostatečně neosvědčilo (Weber a Bel, 2008) a postupně se objevila se celá řada hybridních forem (viz např. Warner, and Hefetz, 2008; Antonioli and Massarutto, 2012; Peda, Argento, and Grossi, 2013; Asquer, 2014; da Cruz and Marques, 2014; Vining, Boardman, and Moore, 2014). Významně pak záleží i na jednotlivých národních prostředích, podmínkách a zvyklostech. Samotná implementace prŕístupů New Public Management je rovněž předmětem kritiky (např. Hood a Peters, 2004; Dunleavy, Margetts, Bastow, a Tinkler, 2006).

Na území České republiky byla do roku 1989 situace pochopitelně odlišná od vyspělých západních zemí. Po roce 1948 došlo ke zrušení vlastnictví měst a obcí a jakkoli 
„komunální služby“ byly poskytovány, podniky komunálních služeb se staly podniky provozovanými městy a obcemi až teprve po obnově vlastnictví obcí a měst (Císař, 1991).

Obce a kraje mohou aktuálně zvažovat tyto základní formy zajišt’ování veřejných statků a služeb (Provazníková, 2009):

- komunální organizace

- obchodní společnosti

- neziskové organizace

- spolupráce mezi obcemi (př́padně kraji navzájem)

Komunální podniky jsou i nadále nezanedbatelnou formou zajištění veřejně poskytovaných služeb v České republice (Petrách, 2013).

Cílem článku je posoudit stav komunálního podnikání v členských státech Evropské unie ve srovnání s Českou republikou, a to s ohledem na proces privatizace a způsobů následného kontrahování služeb tradičně pro občany zabezpečovaných obcemi.

\section{MATERIÁL A METODY}

Výzkum byl zaměřen na postižení procesu privatizace a způsobů následného kontrahování služeb tradičně pro občany zabezpečovaných obcemi. Analýze tedy byly podrobeny systémy kontrahování služeb, konkrétně přístupy popsané ve Velké Británii, Francii, ve Spolkové republice Německo, v Rakousku a ve skandinávských zemích, a následně byla provedena jejich generalizace. První tři země byly vybrány jako exemplární typy veřejné správy (Wollmann, 2011), skandinávské státy pak s ohledem na specifický poválečný společenský vývoj ovlivněný snahou o nalezení kompromisu mezi socialistickými ideami přicházejícími z Východu a kapitalistickými myšlenkami západních zemí (Kananen, 2014). Současně byly využity poznatky prof. Laciny týkající se jak problematiky aktivit komunálních i soukromých malých a středních podniků, které si osvojil v průběhu jeho přednášek na University of Birmingham a Aston University in Birmingham ve Velké Británii, jakož i na řadě evropských a tureckých univerzit, kde v průběhu posledních dvaceti let působil jako hostující profesor.

Ve sběru dat a v jejich následném zpracovávání a vyhodnocování jsme upřednostnili metody pozorování, shromažd’ování dokumentů a obsahová analýza, vedení rozhovorů a generalizace. Polostrukturované rozhovory byly vedeny s představiteli 30 obcí v České republiky. Při stanovování předmětu pozorování jsme dbali na specifikaci základních jevů a zároveň jsme se soustředili na posouzení širších souvislostí sledovaného problému. 
Studium dokumentů zahrnovalo úřední dokumenty, výkazy, publikace, statistiky, noviny, časopisy, videozáznamy.

\section{VÝSLEDKY A DISKUSE}

\section{Zásady hospodaření obcí}

Za jeden z klíčových úkolů veřejné správy je možno označit dlouhodobé zaměření na zvyšování kvality života občanů při respektování zásad udržitelného rozvoje. Z dokumentů i z rozhovorů vyplývá, že z pohledu výkonu veřejné správy se jeho novou dimenzí na počátku 21. století přímo stal „udržitelný rozvoj,, (sustainable development), někdy též označovaný za koncepci „mezigenerační solidarity“. Definice tohoto pojetí rozvoje, v němž se přisuzuje významné místo zvyšování výkonnosti a kvality poskytovaných veřejných služeb byla vypracována $\mathrm{v}$ tzv. Brundtland report (pojmenované po norské předsedkyni Světové komise pro životní prostředí a rozvoj) v roce 1987. Tato definice byla zveřejněna ve zprávě OSN pro životní prostředí a rozvoj nazvané „Naše společná budoucnost" (Our common Future) na první konferenci Organizace spojených národů o životním prostředí konané v roce 1992 v brazilském Rio de Janeiro.

V rámci pojetí udržitelného rozvoje je možno s jistou mírou zjednodušení v obecném pojetí jako prioritní pro první polovinu 21. století definovat tři základní oblasti rozvojových aktivit evropských municipalit:

- zajištění podmínek pro život obyvatel a podnikání;

- formování prostředí pro stimulaci ekonomických činností.

- vytváření předpokladů pro uplatňování občanských aktivit;

Municipality $\mathrm{v}$ rámci snah o efektivní využívání obecního majetku svým občanům poskytují různé veřejné statky financované $\mathrm{z}$ vlastních rozpočtů a $\mathrm{z}$ rozpočtů jejích příspěvkových organizací, jakož i ze zdrojů generovaných municipálními podniky. Další disponibilní zdroje mohou získat díky efektivní spolupráci s místními podnikatelskými subjekty (především cestou uskutečňování zásad Public-Private-Partnership). Jedná se zejména o takové veřejné a veřejně prospěšné služby jakými jsou zajištění bezpečnosti v obci, protipožární ochrana, školské a sociální služby, sběr a likvidace tuhých komunálních odpadů a odpadků, zásobování obyvatel pitnou zdravotně nezávadnou vodou, likvidace odpadních vod, péče o veřejné komunikace a veřejné osvětlení a ochranu životního prostředí. Obecně platí zásada, že obligatorní a fakultativní veřejné a veřejně prospěšné služby mohou být zajištovány municipálním podnikem (dříve převládající 
formou), nebo podnikatelskými subjekty (hlavně malými a středními podniky- a to na základě předcházející privatizace a následného kontrahování výše uvedených služeb).

Mezi významné instrumenty municipální politiky patří institucionální nástroje. Nejčastěji jsou aplikovány dva jejich druhy: vytváření a zakládání různých typů subjektů (například prríspěvkových organizací nebo i soukromých společností), v nichž má obec většinou $100 \%$ podíl nebo rozhodující většinu. Zmíněnou cestou se nejčastěji zabezpečují sběr a likvidace tuhých komunálních odpadů a odpadků, školské a zdravotnické služby, doprava a uskutečňování rozvojových projektů různorodého charakteru.

Za další formu lze označit členství obce (spolu s dalšími aktéry - subjekty veřejné správy, podnikatelské či neziskové subjekty) v dobrovolných svazcích obcí, místních akčních skupinách nebo v různých asociacích (například ve Svazu měst a obcí ČR). V dané souvislosti důležitý potenciál pro budoucí rozvoj nabízí již zmíněná implementace zásad partnerství veřejného a soukromého sektoru (Public-Private-Partnership).

Ilustrace způsobu zajištovóní služeb pro občany na př́kladu aktivit sdružení obcí v západoevropských státech

Vzhledem k napětí v rozpočtech většiny obcí municipality ve většině zemí evropského kontinentu musí hledat cesty k efektivnějšímu zabezpečování svých (především obligatorních) ekonomických aktivit. V členských státech Evropské unie pro zabezpečování obligatorních a fakultativních služeb platí následující obecné zásady:

- hospodaření s municipálním majetkem se musí povinně ř́dit principem maximální hospodárnosti;

- garantuje se právo občanů na průběžnou informovanost o využívání nemovitého a movitého majetku obce (občané jsou de facto pojímáni jako akcionáŕi obce);

- $\quad$ s výjimkou prípadi̊, kdy se municipální majetek prodává proto, aby obec získala prostředky pro financování bydlení v komunálních bytech, vzdělávacích a některých kulturních aktivit a zařizení pro volný čas (výjimečně i pro podporu některých podnikatelských aktivit, na nichž je obec zainteresována) je darování či bezplatné přvádění municipálního majetku nepř́pustné;

- veškeré obchodní transakce s majetkem obce se musí uskutečňovat za plnou tržní сепи.

Z pohledu jejich uskutečňování se realizují následující dva osvědčené přístupy:

a) privatizace služeb pro obce a jejich následné kontrahování od soukromých podnikatelských subjektu;; 
b) formování sdružení obcí.

Zvláště v západni Evropě se vytvářejí sdružení obcí především za účelem:

- společného sběru a likvidace tuhých komunálních odpadů a odpadků;

- zásobování obyvatelstva pitnou a zdravotně nezávadnou vodou;

- likvidace odpadních vod;

- zajištění místní veřejné dopravy;

- podpory místních řemeslnických aktivit;

- podpory rozvoje lokálních turistických aktivit.

Tato sdružení obcí v podmínkách snižujících se dotací do municipálních rozpočtů představují jednu z cest k dosažení vyšší efektivity poskytovaných veřejných a veřejně prospěšných služeb - aniž by se jejich kvalita snížila. Jejich aktivity jsou většinou financovány z:

- př́spěvků od členských obcí;

- poplatků hrazených konzumenty služeb;

- vládních dotací a subvencí.

Pokud jde o sdružování obcí, velmi bohaté zkušenosti mají francouzské municipality sdružené v tzv. Syndicates des Communes. Proto je možno aktivity zmíněných sdružení komparovat se situací v České republice. Syndicates des Communes se obvykle formují tak, že se například v oblasti zajištění dopravní obslužnosti k městu, které má potřebné technické prostředky, přimykají okolní obce, pro jejichž občany se na základě konkrétních dohod zajišt'uje veřejná doprava. Obdobně se postupuje v případě dalších, v první řadě obligatorních, služeb. Ve Francii se vytvořila i některá sdružení obcí zaměřená především na sdružování finančních prostř̌edků pro společnou stavbu nových nemocnic a škol. V téže zemi se jako zvláštní kategorie vytvořila i tzv. Městská společenství sdružující města s minimálně 50000 obyvateli. Působí obvykle na území jednoho departementu. Jejich posláním je:

- společné vypracovávání urbanistických dokumentů;

- koordinace místní veřejné dopravy;

- koordinace výstavby parkovišt’ a garáží;

- koordinace bytové a průmyslové výstavby;

- koordinace protipožární ochrany (zajišt’ované hasičskými záchrannými sbory);

- $\quad$ koordinace rozvoje středního školství. 


\section{Hlavní směry orientace na podporu podnikání v obci}

Přechod k uplatňování zásad New Public Managementu na úrovni obcí postavil volené představitele obcí před základní otázku, zda:

- zajištovat služby výlučně prostřednictvím komunálních podniků nebo

- služby zprivatizovat a zajištovat predevším cestou spolupráce s místními podnikateli.

V obou nastíněných príípadech zastupitelstva obcí musí přijímat rozhodnutí týkající se hledání a využití vhodných prostorů pro podnikání situovaných na katastrálním území municipalit: $\mathrm{V}$ řadě obcí $\mathrm{v}$ České republice mohou být takovéto prostory představovány zejména areály bývalých zemědělských podniků, v jejichž případě existuje nebezpečí, že se $\mathrm{v}$ důsledku jejich dlouhodobého nevyužívání mohou přeměnit v brownfieldy.

$\mathrm{Na}$ úrovni větších municipalit se tak nejednou budují podnikatelské průmyslové zóny, nabízené soukromým podnikatelským subjektům. Dalším možným způsobem rozvoje podnikání v obcích je zakládání tzv. podnikatelských inkubátorů (business incubators). Nastíněný postup je nejen u nás, nýbrž i v dalších členských státech Evropské unie pokládán za efektivní, nebot' usnadňuje účinnou kooperaci hlavních aktérů místního a regionálního rozvoje: zastupitelů a kvalifikovaných úředníků, malých a středních podnikatelských subjektů a neziskových organizací.

\section{Místo malých a středních podniků v ekonomických aktivitách rozvíjejících se na} území obcí

Z analyzovaných dokumentů je zřejmé, že v členských státech Evropské unie se přikládá značný význam spolupráci obcí s kategorií podnikatelských subjektů, pro něž se většinou používá anglické označení „Small and Medium - sized Enterprises“ (SMEs). Jedná se o podniky s menším počtem zaměstnanců, které jsou situovány na území municipalit. Jejich majitelé zde platí daně a využívají místní pracovní sílu. V členských státech Evropské unie malé a střední podniky reprezentují více než 90 \% podnikatelských subjektů a leckde (například v Dánsku) vytvářejí více než dvě třetiny pracovních míst. Angažují se především v oblasti služeb. Podílejí se ovšem rovněž poměrně značnou měrou na řemeslné a průmyslové výrobě. V Evropě a v Severní Americe se dlouhodobě prokázala skutečnost, že malé a střední podniky v porovnání s velkými firmami v převážné většině dosahují vyššího tempa růstu produkce. Jejich příznačným rysem je skutečnost, že jsou poměrně rychle zakládány, avšak současně mnohé z nich zanikají relativně krátce po založení. 
Silnými stránkami malých a středních podniků jsou následující skutečnosti:

- Hledaji (především v počátečních fázích své existence) mezery na trhu, které obvykle úspěšně zaplňují. Vývoji na trhu se snadněji přizpůsobují.

- V porovnání s velkými firmami jsou flexibilnější v přijímání rozhodnutí (o nich rozhoduje bud' jednotlivec, nebo malá skupina osob).

- Strategii podniku určuji ti, kteři přijímají rozhodnutí.

- Jejich vlastníci nejednou pružněji a ochotněji přistupují k inovacím.

- Jsou schopny dosti rychle vytváŕet nová pracovní místa.

Slabé stránky malých a středních podniků spočívají zvláště v následujících faktech:

- Vjednání se zákazníky v porovnání s velkými firmami mají celkově nižši kredit.

- V jednání s bankami i s potenciálními investory jsou rovněž v obtížnějši situaci.

- Z pohledu možného uskutečňování větších projektů obvykle disponují nedostatečnou „rezervni" pracovní silou.

- Mnohdy nemají dostatek zkušeností ze zvládání organizace rozšiřující se výroby.

- Hưře uplatňují nové technologie.

- Mnohdy nemaji dostatečné odborné zázemí, což se mimo jiné odráží v problémech, které jejich majitelé mají zejména se sledováním právních a daňových předpisů.

Porovnáváme-li silné a slabé stránky MSP s parametry velkých podnikatelských subjektů obecně platí, že především z pohledu úkolů zabezpečovaných územní samosprávou velké společnosti se zákonitě programově orientují na velké trhy. Mají relativně vysoké režijní náklady, což jim nedovoluje vyrábět a nabízet produkty v menších sériích. Hůře se přizpůsobují novým požadavkům trhu. Často mají dosti byrokratickou organizační strukturu. Jen obtížně mohou zaměstnávat pracovníky s nízkou kvalifikací. Evropská společenství od roku 1986 (kdy byl přijat tzv. „Akt o jednotné Evropě“ - Single European Act ) i s přihlédnutím k výše uvedeným skutečnostem pokládala dlouhodobou spolupráci mezi představiteli obcí a malých a středních podniků za strategické spojenectví. I dnes Evropská unie takto pojaté spolupráci poskytuje podporu.

Ve prospěch spolupráce obcí s malými a středními podniky hovoří především následující skutečnosti:

1. V prümyslově vyspělých zemích ( $t j$. především v Evropě a v Severní Americe) malé a střední podniky (v první řadě subjekty zaměstnávajíci do 50 zaměstnancư) poskytují místnímu obyvatelstvu až 80 \% pracovních míst (příkladem může být zejména Dánsko).

2. Naproti tomu se mnohde snižuje počet pracovních míst ve velkých podnicích. 
3. Všeobecně platí, že malé a střední podniky dávají poměrně značnou záruku určitého množství potřebných pracovních přiležitostí v obcích a v jejich blízkém okolí.

4. Dalším charakteristickým rysem je skutečnost, že začleňování soukromých podniků do poskytování služeb pro občany obohacuje sit' zmíněných služeb.

5. Vývoj prokázal, že soukromé podnikatelské subjekty působící v tržním prostředí jsou obvykle schopny operativněji a kvalitněji uspokojovat zájmy svých zákazníkư.

6. Vytváření konkurenčního prostředi obsazováním služeb pro obce na základě veřejných soutěži umožňuje obcím sjednávat s vitězi tendrư výhodnějši smluvní ceny.

7. Vr̆adě zemí se konkurence mezi podnikateli ucházejícími se o poskytování zmíněných služeb stala i podnětem $k$ rychlejším inovacím. Pokud v některém velkém městě vedle sebe stojí komunální podnik a soukromé subjekty, jejich konkurenční vztah často ústí v zavádění některých účinnějších postupů v komunálním podniku.

\section{Přínosy kontrahování služeb pro rozvoj spolupráce obcí s podnikatelskými subjekty}

V úvodu zmíněná privatizace a následné kontrahování služeb pro občany v Evropě, ke kterému docházelo od 70. let minulého století, představovaly poměrně složitý proces, pro nějž objektivně existovaly podstatně příznivější předpoklady $\mathrm{v}$ anglosaském systému veřejné správy. Základem tzv. smluvního řízení (contract management/kontraktační management) jsou dohody uzavírané zastupitelstvy obcí a správními úrady na jedné a vítězi veřejných soutěží na druhé straně. Organizování veřejných soutěží musí v rámci úřadů předcházet stanovování klíčových věcných cílů, $\mathrm{k}$ nimž byly následně přiřazeny disponibilní rozpočtové prostředky. Jak připomíná Philippe Keraudren (in Coombes, Verheijen, a kol, 1997, s. 218) „privatizace, smluvní postoupení závazků z veřejného orgánu správy na soukromý subjekt (contracting-out) a průzkum nabídky (market testing) byly generalizovány".

Tento přístup poskytuje voleným představitelům a úředníkům jistou autonomii - avšak současně zvyšuje jejich odpovědnost za kvalitu a včasnost poskytovaných služeb. Teorie konstatuje, že kontraktační management smluvně dává voleným představitelům a pracovníkům veřejné správy $\mathrm{k}$ dispozici určitý objem prostředků za příslib kvalitnějších správních výkonů. Proto $\mathrm{v}$ rámci úřadů je mimořádně aktuálním požadavkem důsledná kontrola dodržování ustanovení smluv. Ta jednak umožňuje zkvalitňovat komunikaci mezi zastupiteli a pracovníky správních institucí zaměřenou na efektivní plnění úkolů veřejné správy, jednak ústí ve vyšší hospodárnost při vynakládání prostředků na jejich 
zabezpečování. Daný přístup usnadňuje důslednější sledování vynaložených nákladů v porovnání s dosahovanými užitky. Je ovšem účinný předpokladu, že se podstatně e zvýšila odpovědnost úředníků za disponování s přidělenými prostř̌edky - a tím i za kvalitu dosahovaných výsledků.

Z výše uvedených důvodů se kontrahování služeb pokládá i za jeden z důležitých předpokladů pro prohlubování kontaktů mezi veřejnou správou na jedné a malými a středními podniky, jež de facto do reforem veřejné správy zabezpečovaly obce, se ukázala potřeba privatizace převážně služeb, u nichž jsou výkony dobře měřitelné, a jejich následné kontrahování. Jedná se o závažný proces, který byl zahájen v anglosaském pojetí výkonu veřejné správy přijetím zákona o povinném kontrahování služeb (Compulsary Competitive Tenderring Act) britskou dolní sněmovnou v roce 1979. Hlavními záměry sledovanými privatizací služeb, jež se v kontinentální části evropského kontinentu uskutečňovala přibližně od poloviny osmdesátých let dvacátého století, byly a zůstává snaha o:

- snižení bezprostředního finančního zatížení municipalit,

- celkové zefektivnění hospodaření obcí,

- nabídnutí občanưm větší výběr služeb.

Obecně je možno konstatovat, že kontrahování služeb, které municipality zajišt’ují pro své občany, představuje na evropském kontinentu jeden $\mathrm{z}$ důležitých nástrojů $\mathrm{k}$ řešení dilematu mezi prrirozeným zájmem občanů na dostupnosti co největšího počtu služeb a omezenými materiálními a technickými možnostmi obcí zabezpečit veškeré požadované služby vlastními silami. V uskutečňování ekonomických aktivit municipalit se jedná se o relativně nový prvek. Kontrahování začalo ve Spojených státech amerických zhruba v období po druhé světové válce, ve druhé polovině šedesátých let ve Velké Británii a více méně až v osmdesátých letech na kontinentální Evropě.

Podstatu kontrahování představuje uzavírání smluv mezi obecním (př́ípadně regionálním) úřadem na jedné a soukromým podnikatelským subjektem na druhé straně. Uskutečňuje se na závěr vyhlášené veřejné soutěže podpisem smlouvy s jejím vítězem. Výhodu obce z kontrahování služeb spatřují především ve skutečnosti, že díky konkurenci mezi účastníky veřejné soutěže mohu dosáhnout nižší ceny služby. Podnikatelé kontrahování vítají především proto, že se jim takto garantuje možnost poskytovat větší množství služeb - a př́ípadně i prodej více výrobků.

V zásadě platí, že se kontrahují především jednodušší - a zároveň dobře měřitelné služby. Jde tudíž převážně o služby, které mají veřejně prospěšnou povahu. Jak již bylo konstatováno, jsou jimi: 
- sběr a likvidace tuhých komunálních odpadů a odpadkü;

- zásobování obyvatel obce vodou, elektrickou energií a plynem

- likvidace odpadních vod;

- zajištování místní veřejné dopravy;

- údržba místních komunikací;

- péče o veřejnou zeleň (predevším o parky ve městech).

Evropské obce se ovšem nevyhýbají ani uzavírání kontraktů na některé větší investiční celky (budované často prostřednictvím sdružení obcí). Jde zejména o výstavbu:

- škol;

- zdravotnických zařizení;

- skládek odpadů;

- spaloven odpadu.

Obce v neposlední řadě uzavírají kontrakty též na služby různých specialistů, v první radě:

- architektů a stavitelì;

- právnikiu;

- pracovníkủ bezpečnostních a informačních agentur.

Ve Spojených státech amerických, ve Velké Británii, ale i v dalších evropských zemích se v praxi obcí stále častěji osvědčují i tzv. „sdružené kontrahování služeb“ a „sdružený nákup zboží,,. Jejich podstatu tvoří dohoda většího počtu obcí (obvykle sousedících) o společném zabezpečování služeb a o nákupu zboží od jednoho podnikatele, nebo od menší skupiny podnikatelů. Skupina obcí takto od podnikatele získává množstevní slevy a podnikatel prodá větší množství služeb, nebo zboží. Výhodou pro oba smluvní subjekty je vyloučení duplicit, které mohou nastat, když obce kontrahují služby individuálně. Navíc se snižuje množství administrativních výkonů - čímž v neposlední řadě dochází $\mathrm{k}$ úspoře lidské práce.

Sdružené kontrahování služeb a sdružený nákup zboží přirozeně kladou zvýšené nároky na kvalifikovanost úředníků municipálních úřadů. Zvláště náročná je příprava smluv $\mathrm{s}$ vítězi výběrových rrízení. $Z$ uvedeného důvodu si sdružení obcí velmi často pro prípravu náročnějších smluv najímají zkušené právníky. Další zvýšené nároky jsou kladeny na úředníky zajišt'ující ekonomiku obcí. I v tomto prrípadě se často osvědčuje najímání zkušených finančních odborníků (v první řadě účetních) pro celé sdružení municipalit.

Sdružené kontrahování se především využívá při společném:

- ukládání odpadů na jedné skládce; 
- spalování odpadí;

- zajištování veřejné dopravy pro město a pro přilehlé vesnice;

- zásobování občanů vodou (někdy i plynem a elektřinou);

- svodu a čišténí odpadních vod;

- koordinaci protipožární ochrany.

Pokud jde o samotný proces kontrahování služeb pro obce, řídí se obdobnými zásadami jako kontrahování probíhající v soukromých podnikatelských subjektech. Třebaže v různých zemích a regionech existují určitá specifika, v zásadě je rozčleněn do následujících šesti etap: První etapa je představována strategickou rozvahou schválenou zastupitelstvem obce (obcí) specifikující v dlouhodobém výhledu - většinou v horizontu deseti až patnácti let - potřeby občanů z pohledu zajišt’ování veřejných a veřejně prospěšných služeb. Velmi často před uvedeným aktem obecní úřady provádějí průzkum mezi občany zaměřený na identifikaci jejich preferencí.

Po schválení takto koncipovaného záměru obecní úradad uskutečňuje průzkum vhodných firem v místě a v blízkém okolí, které by pro zajištění konkrétních služeb mohly připadat v úvahu. Dbá se na to, aby se vytvořilo spravedlivé soutěžní prostředí. Prakticky paralelně se v rámci obecního úřadu stanovuje individuální odpovědnost členů rady a úředníků za přípravu veřejné soutěže a za přípravu kontraktu (kontraktů). Následně obecní úřad provádí specifikaci veškerých činností, které jsou s poskytováním konkrétních služeb spjaté a nechává vypracovávat studie porovnávající náklady při zajišt’ování služby kapacitami obce a nájmem od soukromého podnikatelského subjektu.

Teprve $\mathrm{v}$ další fázi se vypisuje veřejné soutěž, která je povinně oznámena na úřední desce úřadu. Postupuje se tak hlavně proto, že se musí př́ísně dbát na to, aby byli všichni zájemci stejným způsobem informováni. Určuje se zároveň místo v obecním úřadu, v němž zájemci obdrží další informace a kam jsou v př́islušné stanovené lhůtě povinni doručit své nabídky, které jsou pak úřadem zveřejněny. $\mathrm{Na}$ uvedeném základu obecní úřad vypracovává seznam účastníků veřejné soutěže, který je rovněž na viditelném místě - tj. na úřední desce- zveřejněn. $\mathrm{Na}$ závěr zmíněné fáze je $\mathrm{s}$ vítězem podepisován kontrakt. Podpisem kontraktu ovšem celý proces zdaleka nekončí. V další etapě se role obecního úřadu ještě podstatněji zvyšuje.

Nastupuje kontrolní fáze, která by měla de facto zahrnovat celé období platnosti smlouvy uzavřené obecním úřadem s poskytovatelem služby. Obecní úřad v ní především vyhodnocuje:

- informace, které mu podnikatel průběžně poskytuje; 
- př́padné stížnosti občanů na včasnost a na kvalitu prováděné služby

$a(v$ neposlední řadě)

- poznatky z vlastní kontrolní činnosti.

Pokusíme-li se o jisté zobecnění forem a metod spolupráce mezi uvedenými subjekty, do popředí vystupují především následující:

a) v oblasti územního plánování:

představitelé obcí stále častěji spolupracují s mistními podnikateli při upřesňování územních plánů:(včetně úvah o př́ípadném budování průmyslových zón).

b) při podpoře aktivit podnikatelů:

- municipality často novým podnikatelưm, na jejichž činnosti mají zvýšsný zájem, výhodně poskytují (formou pronájmu či prodeje) obecní budovy a další zařizení ve vlastnictví obce,

- obce často zakládají tzv. podnikatelské inkubátory (business incubators), což jsou zařízení umístěná v obecních budovách, do nichž jsou situovány vybrané začínající malé firmy. Firmy v nich platí nižší nájemné, obec jim často levně (či bezplatně) vede účetnictví a pomáhá s dalšími administrativními pracemi. Nové podnikatelské subjekty jsou v ,podnikatelských inkubátorech“ obvykle situovány po dobu tří let. Tato lhůta vychází z mnohaletých zkušeností, které říkají, že nová firma, která přežije první tři roky své existence, je zralá a může tudíž efektivně působit $\mathrm{v}$ běžném podnikatelském prostředí,

- podnikateli̊m, kteři chtějí rozvíjet své aktivity na území obce, municipality - pokud se tyto záměry nacházejí v souladu s jejich dlouhodobými prioritami - často poskytují bydlení v komunálních bytech, nebo jim výhodněji prodávají domy v jejich vlastnictví.

c) ve finanční oblasti obce:

- vybraným podnikatelưm ručí u bank za úvěry;

- nejednou vybraným podnikům poskytují ze svého rozpočtu př́mé dotace;

- vybraným podnikům diferencovaným způsobem udělují daňové úlevy;

- diferencovaně stanovují podnikatelưm místní poplatky, v první řadě lázeňské a z provozu rekreačních, školících a ubytovacích zařizení na území municipalit.

d) v legislativní oblasti

- obce při vydávání vyhlášek a nařizení s mistní působností vytvářejí prríznivé (případně nepř́znivé) podmínky pro rozvoj podnikatelské činnosti na jejich území. 
e) v oblasti podpory zaměstnanosti občanů zvyšování jejich kvalifikace obce:

- s místními podnikateli spolupracují při vytvárení pracovních míst pro nezaměstnané a pro zdravotně postižené osoby;

- podporují uskutečňování různých rekvalifikačních programů (v této souvislosti spolupracují zejména s řemeslnickými a dalšími živnostenskými komorami).

f) v dalších oblastech činnosti obcí

Obce nejednou s místními podnikateli zakládají a provozují společné podniky angažující se především v poskytování některých veřejně prospěšných služeb.

\section{ZÁVĚR}

Obcemi vlastněné podniky, využívané ke zprostředkování statků a služeb s vysokými náklady poptávanými občany jsou často předmětem diskusí a pochybností, pokud jde o jejich efektivitu a účinnost, tedy ekonomické vynaložení nákladů (Petrách, 2012). Liberální proudy v politickém myšlení vedly zejména v 80. letech 20 . století v mnoha vyspělých zemích k zahájení privatizace tohoto sektoru. Úplná privatizace se však př́liš neosvědčila a postupně se tak rozvinulo široké spektrum smíšených komunálních podniků se zastoupením samospráv i soukromého vlastnictví.

V řadě evropských zemí úspěšně funguje zajišstování veřejných služeb pro obyvatele obcí sdružením obcí, a to bud' prostřednictvím společných komunálních podniků, nebo společným zadáváním těchto služeb soukromým subjektům. V České republice v 90. letech vznikla celá řada dobrovolných svazků, které však právě k výše zmíněnému účelu př́liš neslouží. I proto byl $\mathrm{v}$ roce 2005 předložen návrh Ministerstva vnitra ČR na vytvoření nového modelu spolupráce obcí, tzv. „společenství obci““, které by, díky svému specifickému charakteru, mohlo dobře fungovat právě např́klad v oblasti společného zajištování veřejných služeb. Tento návrh ovšem neprošel zejména kvůli finanční otázce, jelikož z rozpočtového určení daní nebyly vyčleněny dostatečné prostředky na finanční motivaci. Podle Ministerstva vnitra ČR se měla společenství obcí podílet na rozpočtovém určení daní, což by bez navýšení prostředků na samosprávu znamenalo pokles přímých př́ijmů obcí.

Na základě výzkumu i studia dostupných pramenů lze rovněž konstatovat, že i po privatizaci veřejných a veřejně prospěšných služeb se nezměnila angažovanost obcí a regionů v zajišt'ování veřejných a veřejně prospěšných služeb. 


\section{SUMMARY}

The municipality-owned enterprises designated for providing the high costly goods and in order to satisfy the citizens' demand subject to frequent discussions as for their efficiency and cost-effectiveness. The discussion strengthened in 1970 with the frequent shortage within public budgets as well to the influence of the so called New Public Management ideas. Liberal political movements led particularly in 1980s in many developed countries to the initiation of the process of privatization of this sector. The complete privatization rather failed, though. The following period witnessed the development of a wide spectrum of hybrid forms of municipal enterprises with participation of both the municipalities and the private bodies. The aim of the paper is to discuss the situation of the municipal entrepreneurship in some EU member countries (namely Great Britain, France, Germany, Austria and Scandinavian countries) with regards to the process of privatization running out since later 1970 s and the subsequent outsourcing of contracting the municipal service provision by private companies. The findings are compared with the situation in the Czech Republic. The analyses were done based on collecting date by means of the observations, semi-structured interviews and available documents, such as reports, statistics, articles in press or videos. The content analysis was employed in order to process data from collected documents. The procurement of public services for citizens of individual settlements proved to be quite successful by means of collective communal enterprises or through the joint contracting of these services by a group of municipalities with the private entities. In Western Europe, municipalities associates particularly in order to assure in common:

- collection and disposal of municipal solid waste;

- supply of harmless drinking water

- disposal of waste water;

- local public transport

- $\quad$ support to local artisans' activity

- $\quad$ support to the development of local tourism activities

There is also a frequent co-ordination of the fire protection (fire and rescue service).

A number of voluntary bundles of municipalities were created 1990s in the Czech Republic but there was no significant result in joint contracting of joint providing of municipal services to their citizens. There are also still some legal and fiscal issues that rather discourage municipalities from such an effort. Despite the proposal by the Ministry of the Interior presented in 2005 that suggested a new model of the so called "communities of municipalities" there is no legislative progress in this situation.

\section{LITERATURA}

Antonioli, B., Massarutto, A. (2012). The municipal waste management sector in Europe: shifting boundaries between public service and the market'. Annals of Public and Cooperative Economics, 83, 4, 505-532.

Asquer, A. (2014). Explaining partial privatization of public service provision: The emergence of mixed ownership water firms in Italy (1994-2009). Annals of Public and Cooperative Economics, 85, 1, 11-30.

Aucoin, P. (1990). Administrative Reform in Public Management: Paradigms, Principles, Paradoxes and Pendulums. Governance: An International Journal of Policy and Admministration. Vol. 3, No. 2, pp. 115-137. DOI: 10.1111/j.1468-0491.1990. tb00111.x

Císař, J. (1991). O vlastnictví měst a obcí. Finance a úvěr. 41 (1), pp. 17-24

Coombes, D., Verheijen, T. a kol. (1997). Reforma verejnej správy:porovnanie skúseností Východu a Západu“. Evropská komise, 478 p.

da Cruz, N.F., Marques, R.C. (2014). Mixed companies as local utilities. Proceedings of the Institution of Civil Engineers: Municipal Engineer. Vol. 167, No. 1, pp. 3-10

Dilger, R.J., Moffett, R.R. and Struyk, L. (1997). Privatization of Municipal Services in America's Largest Cities. Public Administration Review. 57 (1), pp. 21-26.

Dunleavy, P., Margetts, H., Bastow, S., Tinkler, J. (2006). New Public Management Is Dead-Long Live Digital-Era Governance. Journal of Public Administration Research and Theory. Vol. 16, No.3. 467-494 
Dušek, J., Pána, L. (2012). Zdravá města a Místní Agenda 21. České Budějovice: VŠERS, $144 \mathrm{p}$.

Fuller, E., Casner, A.J. (1941). Municipal Tort Liability in Operation, Harvard Law Rewiew, 54 (3), pp. 437-462, 26 p.

Hebdon, R., Jalette, P. (2008). The restructuring of municipal services: a Canada - United States comparison. Environment and Planning C: Government and Policy. 26 (1), pp. 144-158. doi:10.1068/c0634

Hood, C., Peters, G. (2004). The Middle Aging of New Public Management: Into the Age of Paradox? Journal of Public Administration Research and Theory, 14 (3), pp. 267 282. DOI: $10.1093 /$ jopart/muh019

Kananen, J. (2014). The Nordic Welfare State in Three Eras: From Emancipation to Discipline. Ashgate Publishing Ltd. 218 s. ISBN: 978-140945773-2

Chandler, J. A. (1998). Místní správa v liberálních demokraciích, Brno: Nakladatelství Doplněk

Kočíková P. (1998). Evropská unie a životní prostředí: politiky, strategie, legislativa. Ostrava (Montanex).

Lamming, R.,Bessant, R. (1995). Macmillanưv slovník podnikání a managementu, Praha: Management Press.

Lacina, K., Kala, T. (2003). Regionální a mezinárodní marketing, Hradec Králové: Gaudeamus.

Ochrana, F. (2002). Manažerské metody ve veřejném sektoru: teorie, praxe a metodika uplatnění, Praha: Ekopress, s. 216.

Ochrana, F. (2003). Veřejné služby - problém vymezení pojmu a standardizace. In Standardizace veřejných služeb jako předpoklad efektivnosti rozvoje regionů. Brno: Masarykova univerzita, ESF, pp. 16-21.

Ochrana, F., Pavel, J., Vítek, L. (2010). Veřejný sektor a veřejné finance: financování nepodnikatelských a podnikatelských aktivit. Praha: Grada Publishing, 264 p.

Peda, P., Argento, D., Grossi, G. (2013). Governance and Performance of a Mixed PublicPrivate Enterprise: An Assessment of a Company in the Estonian Water Sector. Public Organization Review. 13, (2), pp. 185-196

Petrách, F. (2012). Komunální podniky ve struktuře právnických osob v České republice. Sborník INPROFORUM Junior 2012. Č. Budějovice: EF JU, s. 182-190.

Petrách, F. (2013). Komunální podniky - jejich cíle a fungování v moderní ekonomice. Disertační práce. Č. Budějovice: EF JU, 169 s.

Provazníková, R. (2009). Financování měst, obcí a regionů. 2. aktualizované a rozš́řrené vydání. Praha: Grada Publishing, 304 s.

Thomson, M., Barlov, R. G. (2012). Dialing Up Delivery: A Renewed Frontier for Health Care Value, Benefits quarterly, First quarter 2012

Vining, A. R., Boardman, A. E., and Moore, M. A. (2014), The Theory and Evidence Pertaining to Local Government Mixed Enterprises. Annals of Public and Cooperative Economics, 85: 53-86. doi: 10.1111/apce.12029

Warner, M. E., Bel, G. (2008). Competition Or Monopoly? Comparing Privatization Of Local Public Services in the US and Spain. Public Administration, 86, (3), pp. 723735. doi: 10.1111/j.1467-9299.2008.00700.x

Warner, M. E., Hefetz, A. (2008). Managing markets for public service: The role of mixed public-private delivery of city services. Public Administration Review, 68 (1), pp. $155-166$

Wollmann, H. (2011). Provision of Public Services in European Countries: From Public/Municipal to Private and Reverse? Hrvatska i Komparativna Javna UpravaCroatian and Comparative Public Administration, 11, (4), pp. $8 \quad 89-910$ 
Wöhe, G., Kislingerová, E. (2007). Úvod do podnikového hospodářství, 2. vydání. Praha: C.H.Beck, $928 \mathrm{~s}$.

Wright, G., Nemec, J. (2003). Management veřejné správy: teorie a praxe zkušenosti z transformace veřejné správy ze zemí střední a východni Evropy. Praha: Ekopress. 